\title{
HABITATS WITH SEA GRAPE (EPHEDRA DISTACHYA) ON THE DUNES OF LETEA (DANUBE DELTA, ROMANIA)
}

\author{
Erika SCHNEIDER-BINDER * and Felizia KUHLKE ** \\ * Karlsruhe Institute for Technology - University of Land Baden-Württemberg and Research Center of \\ the Helmholtz Society, Institute for Geography and Geoecology, Department WWF-Institute for \\ Floodplain Ecology, Josef Strasse 1, Rastatt/Germany, D-76437, erika.schb@t-online.de \\ ** Landratsamt Böblingen, Wasserwirtschaft/Oberirdische Gewässer, Grundwasserschutz, Park Strasse \\ 16, D-71034, Böblingen, f.kuhlke@lrabb.de
}

DOI: 10.1515/trser-2015-0062

KEYWORDS: grey dunes, pioneer colonisation, adaption to extreme dryness, xerothermophilous vegetation, ecological gradients, groundwater table.

\section{ABSTRACT}

The Danube Delta is known for its unique, biogeographical-important ecosystem complex that includes a large range of habitats from the permanently water-covered to the extremely dry area. These ecosystems are well represented in the area nearest to the Black Sea in the dune area of Letea, Caraorman and Sărăturile. Sea grape (Ephedra distachya) communities taking part of the habitat type 2130* fixed coastal dunes with herbaceous vegetation (grey dunes), Subtype 16.22 B Pontic fixed dunes and their classification in the European habitat system are discussed and a proposal is made for their appropriate integration in a corresponding category of habitat types in the frame of the Pontic bioregion.

ZUSAMMENFASSUNG: Lebensräume mit Meerträubchen (Ephedra distachya) auf den Dünen von Letea (Donau-Delta, Rumänien).

Das Donau-Delta ist bekannt für seinen einzigartigen Ökosystemkomplex von großer biogeographischer Bedeutung, der von ständig wasserbedeckten bis hin zu extrem trockenen Bereichen eine weite Spanne von Lebensräumen umfasst. Die ausgeprägt trockenen Bereiche konzentrieren sich auf den Meer nahen Bereich des Deltas und zwar auf die Dünengebiete von Letea, Caraorman und Sărăturile. Die Bestände des Meerträubchens (Ephedra distachya), die dem Habitatyp 2130* Festliegende Küstendünen mit krautiger Vegetation (Graudünen), Subtypus 16.22 B Pontische festliegende Dünen zugeordent sind, werden diskutiert und eine entsprechende Einordnung der Meerträubchenbestände im System der Habitattypen der pontischen Bioregion vorgeschlagen.

REZUMAT: Habitatele cu Ephedra distachya de pe dunele de la Letea (Delta Dunării, România).

Delta Dunării e cunoscută pentru unicul său complex de ecosisteme de importanţă biogeografică, cuprinzând o largă amplitudine de habitate, de la zone permanent acoperite cu apă până la locuri extrem de uscate. Ariile cele mai uscate se concentrează în delta maritimă şi anume pe dunele de la Letea, Caraorman şi Sărăturile. Fitocenoze edificate de cârcel (Ephedra distachya) făcând parte din tipul de habitat 2130* - Dune de coastă cu vegetaţie erbacee (dune gri), Subtipul 16.22 B Dune fixate pontice - dune fixate de pe Coastele Mării sunt discutate şi analizate din punct de vedere ecologic şi al integrării în sistemul de habitate europene de dune, fãcând-se propunerea pentru o mai adecvată integrare în cadrul bioregiunii pontice. 


\section{INTRODUCTION}

The Danube Delta is $4,180 \mathrm{~km}^{2}$ (Gâștescu and Știucă, 2008), of which $84 \%$ is situated in Romania. It is one of the largest wetlands of Europe, and known worldwide for its unique, biogeographical important ecosystems, including a large range of habitats from the permanently water covered to the extremely dry. The diversity of the habitats is reflected through the remarkable diversity of plant and animal species and their coenoses. The delta shelter, with $1,560 \mathrm{~km}^{2}$, is one of the worldwide largest, compact reed areas edified by Phragmites australis, with large floating reeds. The so-called "Plaur", gallery-like white willow softwood, stands along the Delta branches. Sheltering species adapt to extreme conditions, such as large water bodies covered by floating, emerged and submerged macrophytes as well the maritime part dune area, partly with extremely dry sites. The largest dune complexes are those of "Grindul Letea", north of the Sulina branch, "Grindul Caraorman", and "Grindul Sărăturile", between Sulina and Sfântu Gheorghe Branch.

The so-called "Grind" area of the Danube Delta is also represented, according to Antipa (1911), by high elevations of various genesis. On the one hand, there are natural river bank levees named in Romanian "grinduri de mal", emerged by the continuous dynamics of the Danube deposits during high floods fine sized sediments on the river banks. On the other hand, in the Delta high elevations of continental origin - the Grindul or "Plain" of Chilia (Câmpul Chiliei) and Grindul Stipoc, rests the Bugeac Plain with loess depositions of quaternary age rising up to one to $13 \mathrm{~m}$. The third category, the above mentioned Grinds of Letea, Caraorman and Sărăturile are marine levees, old beach barrier complexes, composed by Sea mussels and sand (Gâştescu and Ştiucă, 2008). These dunes are almost fixed, but there are also some areas on the coast near Sfântu Gheorghe Branch which are in a less fixed state. The fan-like dunes of Letea (Fig. 1) and Caraorman with their dune ridges and dune depressions offer a rich structured and multifaceted complex of habitats sheltering a very specific and unique vegetation and fauna in a range of habitats. These habitats vary depending on the dunes exposure to sun and the related level of dryness, as well as the alternation between dunes and depressions between them. These dune depressions are occupied locally by shrubs of Salix rosmarinifolia at the initial stage, and by a type of floodplain forest with changing ground water table, being edified by oaks (Quercus robur, Quercus pedunculiflora) and ash (Fraxinus pallisae, Fraxinus angustifolia), as well as lianes such as Silke wine (Periploca graeca) and Wild wine (Vitis sylvestris), singular in its structure and biodiversity (Borza, 1931; Hanganu et al., 2015; Schneider, 2015). Dominate steppe vegetation with pontic and continental-Eurasian xero- and thermophilous species are on the top of the dunes with elevations of $+12.00 \mathrm{~m}$ (Caraorman) and $+14.00 \mathrm{~m}$ in the Letea area (Cioacă et al., 2005; Gâş̧tescu and Ştiucă, 2008).

These more or less open dunes, entering in the majority of the category of grey dunes, are colonised by characteristic species of mostly dry sands and are included in the priority habitat type 2130* - Fixed coastal dunes with herbaceous vegetation (grey dunes), subtype 16.22 B - Pontic fixed dunes - of the coasts of the Black Sea (EUR 28, 2013; Gafta and Mountford, 2008; Fig. 2). One of the edifying species typical for the dune habitats on the Black Sea coasts, including the Danube Delta, is the Sea grape (Ephedra distychya), known in particular from the Letea dune area and "holding on with success on the higher levels of the dunes" (Borza, 1931). But these grey dunes have so many colonizers: edifying different phytocoenoses in different microhabitats; depending on the dunes altitude, exposition and related dryness; that it has to be clarified; if it is justified to include them all in the above mentioned habitat type of grey dunes; or each in separate habitat type. This consideration is related to the fact that there are also more detailed delineated habitat types for dune areas, edified each by characteristic species and not included in the habitat type of grey dunes. 
Part of our considerations is as well the fact, that the grey dunes of the Black Sea coast and the Danube Delta are included in the category of habitat types of "Sea dunes of the Atlantic, North Sea and Baltic coasts" as the "subtype 16.22 B - Pontic fixed dunes - fixed dunes of the coasts of the Black Sea" although they occur in the Black Sea/Pontic Bioregion. This Bioregion is strongly related in its Southern part to the Mediterranean Bioregion and as well interlocked with the Steppic Bioregion. The Black Sea Pontic Bioregion - including the marine part of the Danube Delta - shelter some habitat types between others, the habitat type 1410 Mediterranean salt meadows (Juncetalia maritimi), characteristic for the Mediterranean Bioregion, occurring in the area of the Southern Sfântu Gheorghe Branch and the Popina area situated on the lower part of the Chilia Branch.

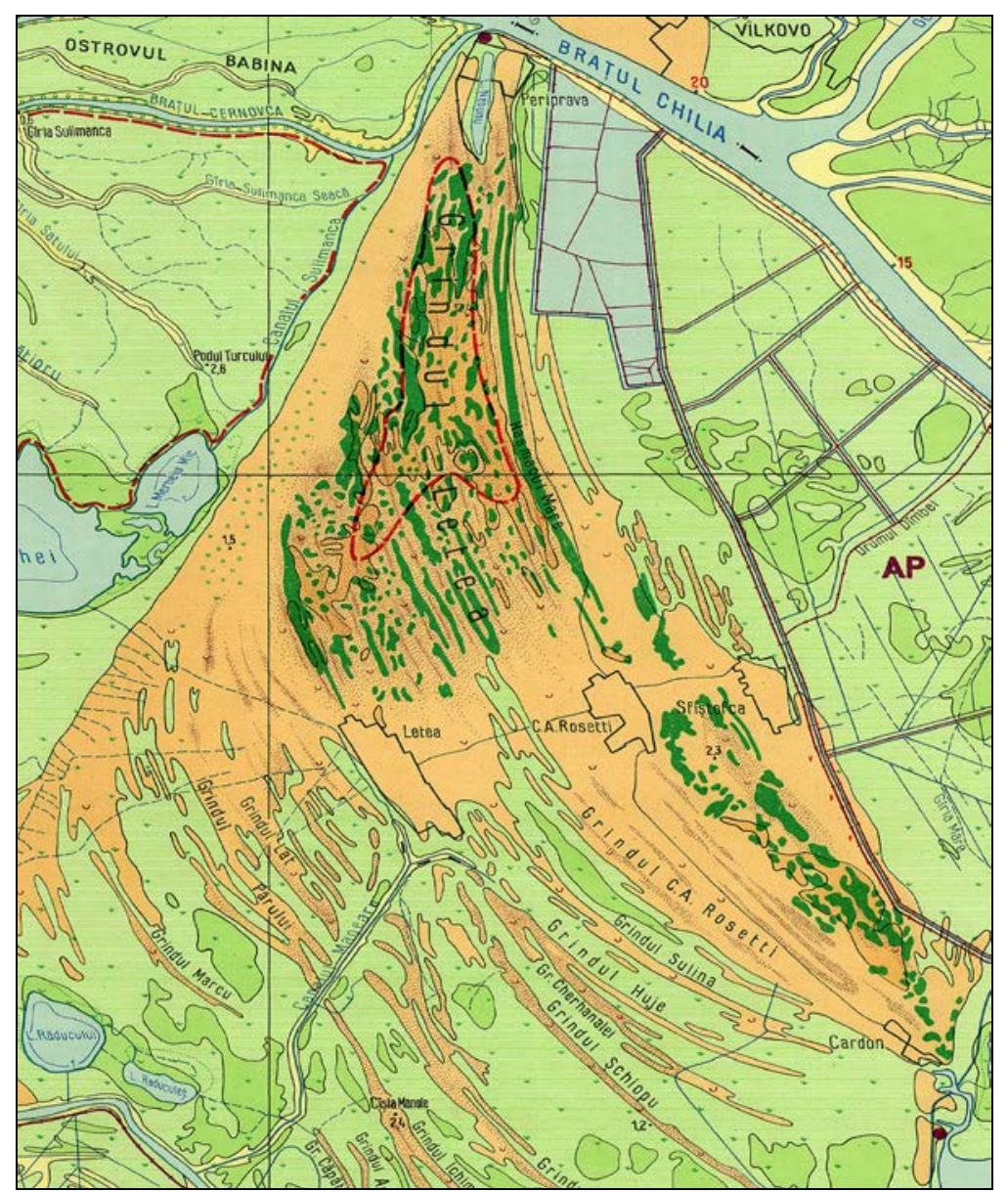

Figure 1: The Letea dune area showing the Letea Forest patches, the three villages Letea, C. A. Rosetti and Sfiştofca and surrounding area (Gâştescu, 1992 - detail of Touristic map of the

Danube Delta). With red border is the strictly protected dune area.

Taking into account these facts, the objective of this paper is to analyse the habitat with Ephedra distachya in strong relation with other habitats of the area which are characteristic for the Steppic and the Pontic/Black Sea Bioregion, as well as the Mediterranean Bioregion, and to propose the appropriate type of habitat, subhabitat or category of habitat types of the above mentioned two bioregions in which it can be included. 


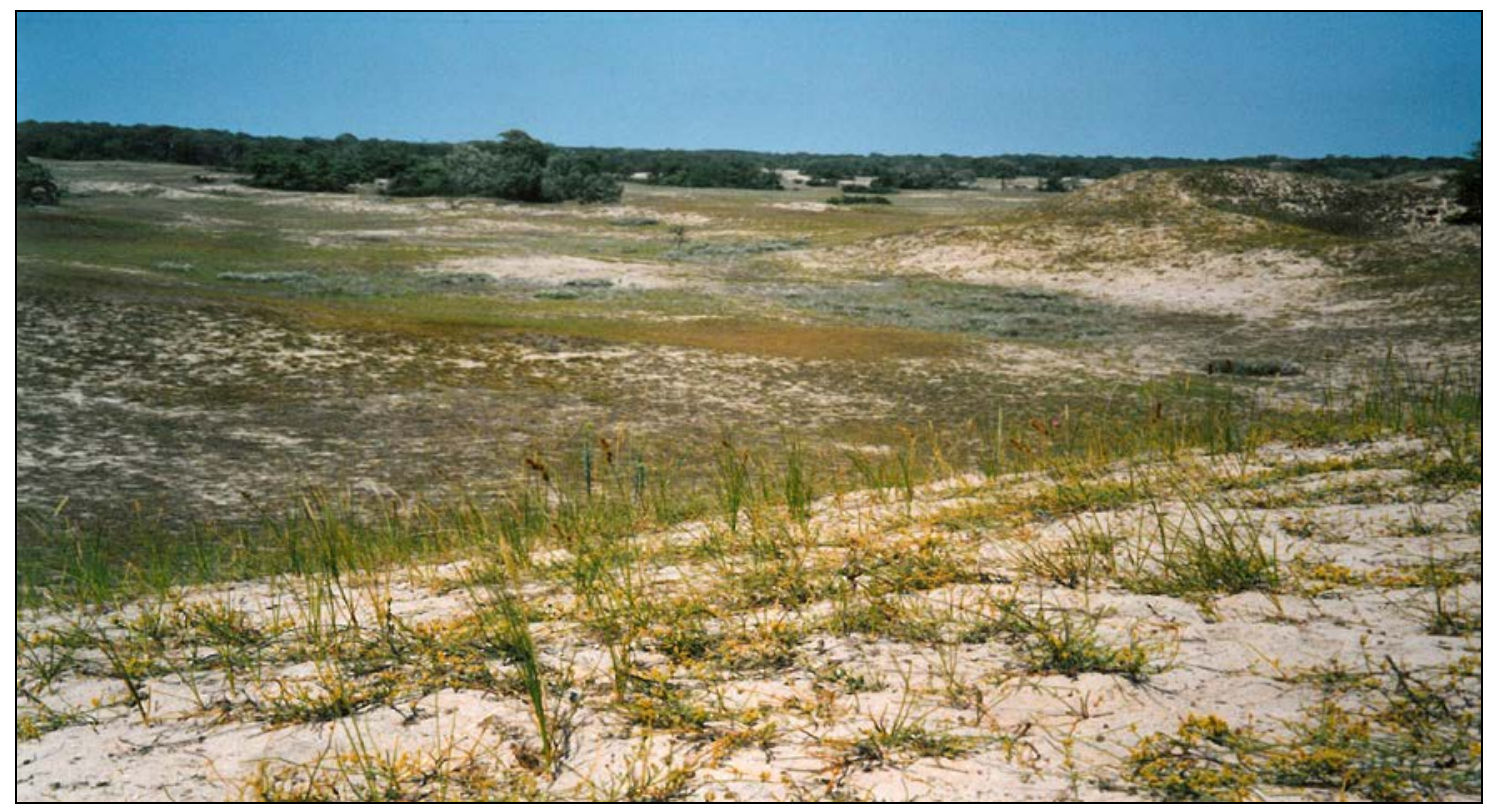

Figure 2: Dune area of Letea with different type of dune vegetation:

Ephedra distachya and Carex colchica in the foreground, dune slacks with Salix rosmarinifolia and forests in the background.

\section{MATERIAL AND METHODS}

The pioneer vegetation of the Letea dune area has been studied during field researches in the Danube Delta in September 2011. Some earlier data from the year 2003 from Letea dune Omer, the highest elevation, has been included. Samples were taken according to the method of Braun-Blanquet with the seven degree abundance-dominance scale (Braun-Blanquet, 1964; Borza and Boşcaiu, 1965). The taken samples are included in a phyto-coenological table where it is mentioned the distribution area of each species according to the data from Romanian Flora works (Ciocârlan, 1994, 2009; Oprea, 2005; Sârbu et al., 2013) and compared with data of other mentioned phytocoenoses and habitats edified by Ephedra distachya (Sanda et al., 2008; Doniţă et al., 2005; Horvat et al., 1974; Krausch, 1965; Simon, 1960). The nomenclature of species is used according to Sârbu et al. (2013), Ciocârlan (2009), and partly Oberdorfer (2001).

\section{RESULTS AND DISCUSSIONS}

Dunes with phytocoenoses edified by Sea grape (Ephedra distachya) are mentioned from the Black Sea coast in the dune area of Agigea near Constanța, the Caraorman and the Letea dune complexes, near Sulina, Gura Portiţei (Borza, 1931; Grinţescu, 1952; Simon, 1960; Krausch, 1965; Sanda and Popescu, 1973; Făgăraş, 2002; Sanda et al., 2008; Hanganu et al., 2015; Schneider, 2015), Grindul Chituc (Sârbu et al., 1995; Făgăraş, 2002), Mamaia, Eforie, Techirghiol, Grindul Saele (Făgăraş, 2002). Ephedra distachya is part of the Gymnospermae, Order Gnetales and Ephedraceae family, being a dioic scrub (Figs. 3 and 4), growing erectly, or prostrate, ramified on the base, with flexible nodose branches, being well adapted through its morphological structure to the dry conditions on the Southern, South-Eastern and SouthWestern exposed slopes of the dunes. It occurs more on the upper part of the slopes and on the top of the dunes, as it can be observed at the dune with the highest elevation, the Omer-dune in the fan-like dune complex of Letea. 


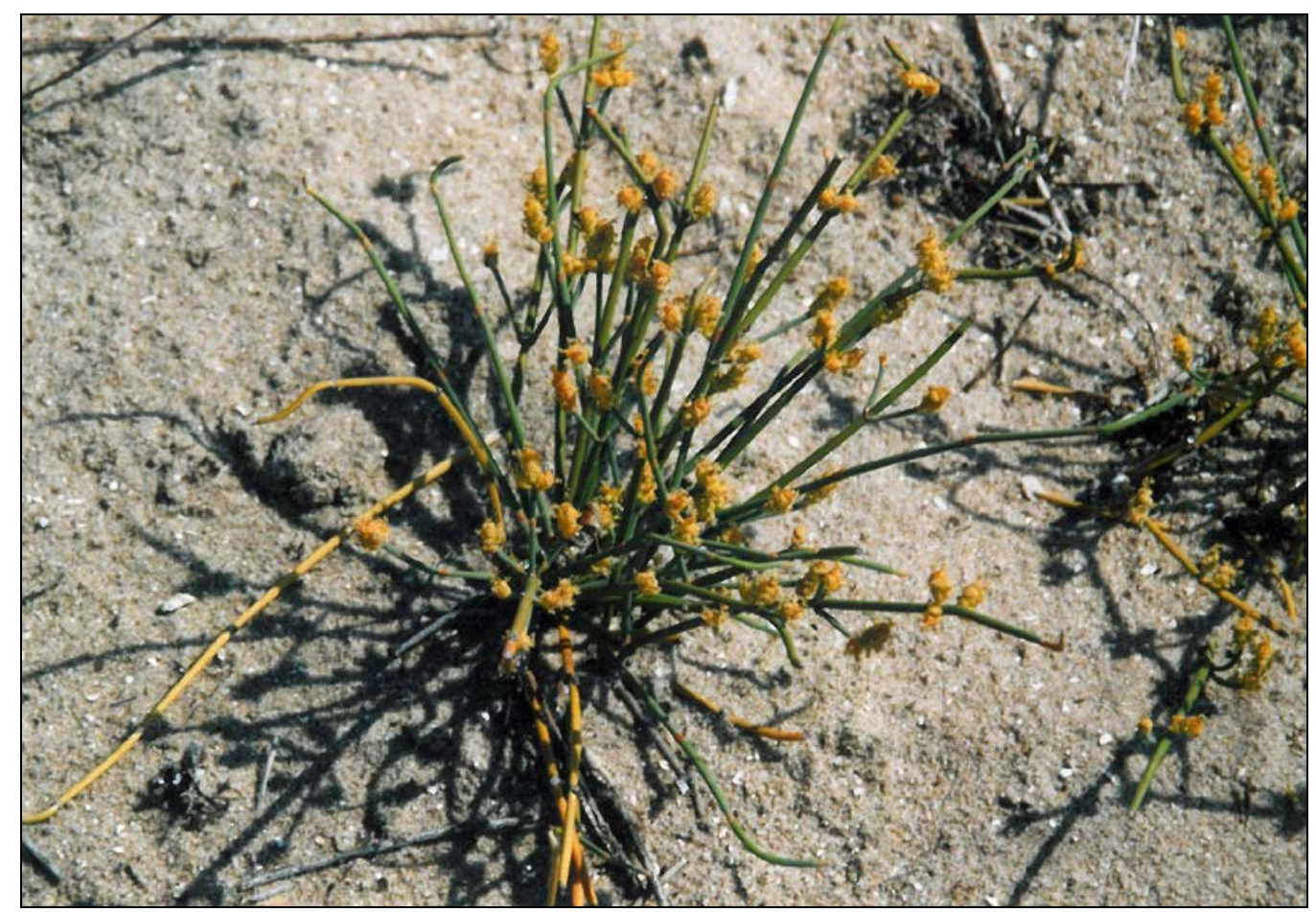

Figure 3: Ephedra distachya male plant on the dune Omer/Letea dune complex (photo Schneider E., 2011).

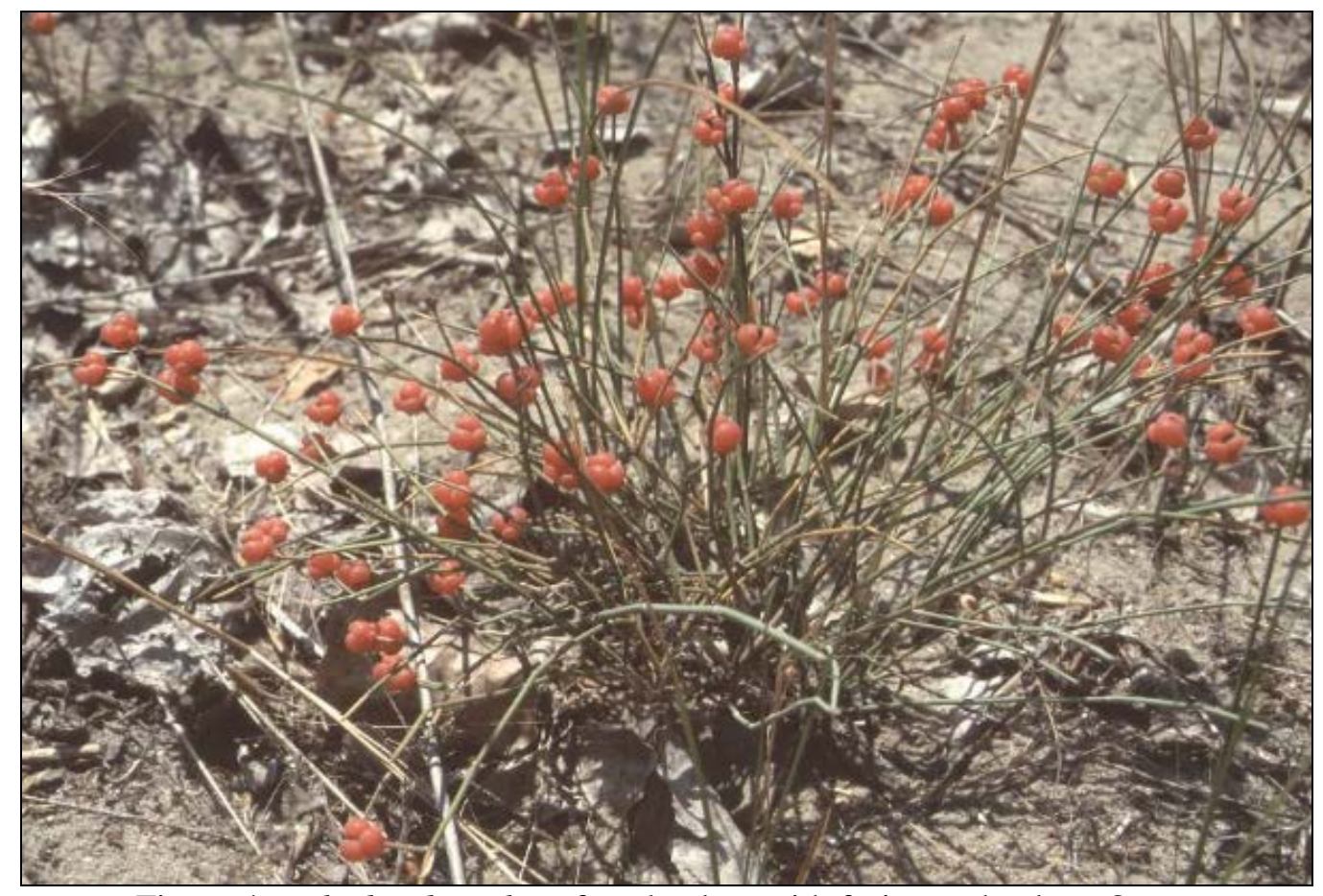

Figure 4: Ephedra distachya, female plant with fruits on the dune Omer,

Letea dune area in 2011. 
On the dunes the Sea grape forms mostly open pioneer stands together with other species well adapted to the dry conditions of the top of the dunes. It edifies characteristic phytocoenoses in particular with Carex colchica, Polygonum arenarium, Euphorbia seguieriana and other arenophilous and xero-thermophilous species (Tab. 1).

Following the disposition of vegetation on the dune slopes, a clear ecological gradient can be remarked. On the foot of the dunes with existing influence of the changing groundwater table, phytocoenoses of Scirpoides holoschoenus (Holoschoenus vulgaris) occurs. In their lower part, they are locally in contact with dune slacks edified by Salix rosmarinifolia. On the upper part of the slopes are interlocking with phytocoenoses of Carex colchica with frequent facies of Ephedra distachya to the top of the dunes and accompanied by other xerotheromophilous species (Simon, 1960). This is the site where the Sea grape is growing in abundance. On the top of the dunes, it occurs also together with Festuca beckeri ssp. arenicola and Stipa borysthenica.

According to Sanda et al. (2008) Ephedra distachya occurs in phytocoenoses of the association Scabioso argenteae-Caricetum colchicae (Simon, 1960) Krausch 1965 (Syn. Caricetum colchicae Simon, 1960; Carici colchicae-Holoschoenetum vulgaris Ștefan and Sârbu, 1995) subass. ephedretosum Sanda et al., 1999 (Syn. Ephedro-Caricetum colchicae (Prodan n.n., Morariu, 1959) Sanda and Popescu, 1973). In these phytocoenoses, the Sea grape develops abundantly and it seems to be - according to our own observations - in continuous expansion. Similar observation where made also at Grindul Chituc (Sârbu et al., 1995).

Table 1: Scabioso argenteae-Caricetum colchicae (Simon 1960) Krausch, 1965, subass. ephedretosum Sanda et al., 1999; 1. Dune Omer/Letea 5.06.2003; 2-14 Dune Omer and proximity 08.09.2012.

\begin{tabular}{|c|c|c|c|c|c|c|c|c|c|c|c|c|c|c|c|}
\hline & $\begin{array}{l}\text { Sampling } \\
\text { number }\end{array}$ & 1 & 2 & 3 & 4 & 5 & 6 & 7 & 8 & 9 & 10 & 11 & 12 & 13 & 14 \\
\hline & $\begin{array}{l}\text { Covering } \\
\text { degree \% }\end{array}$ & 45 & 20 & 20 & 25 & 35 & 10 & 20 & 25 & 45 & 20 & 55 & 25 & 40 & 30 \\
\hline \multicolumn{16}{|l|}{$\begin{array}{l}\text { Flor.- } \\
\text { elem. }\end{array}$} \\
\hline & $\begin{array}{l}\text { Scabiosion } \\
\text { argenteae } \\
\text { Festucetalia } \\
\text { vaginatae }\end{array}$ & & & & & & & & & & & & & & \\
\hline Ct-Eua & $\begin{array}{l}\text { Ephedra } \\
\text { distachya }\end{array}$ & 3 & 2 & 2 & 1 & 3 & 1 & 1 & 2 & 3 & + & 3 & 2 & 3 & 2 \\
\hline$P$ & $\begin{array}{l}\text { Carex } \\
\text { colchica }\end{array}$ & 1 & + & . & . & . & . & . & . & . & + & . & . & + & 1 \\
\hline P-Balc & $\begin{array}{l}\text { Scabiosa } \\
\text { argentea }\end{array}$ & + & . & . & . & . & . & . & . & . & . & . & + & + & . \\
\hline $\begin{array}{l}\text { P-Pan- } \\
\text { Md }\end{array}$ & $\begin{array}{l}\text { Polygonum } \\
\text { arenarium }\end{array}$ & + & + & . & . & . & + & + & + & 1 & 2 & + & + & + & + \\
\hline P-Med. & $\begin{array}{l}\text { Cynanchum } \\
\text { acutum }\end{array}$ & . & . & . & . & . & . & . & . & . & . & . & . & & + \\
\hline $\mathrm{P}$ & $\begin{array}{l}\text { Stipa } \\
\text { borysthenica }\end{array}$ & + & • & . & . & . & . & . & . & . & . & . & . & & \\
\hline
\end{tabular}


Table 1 (continued): Scabioso argenteae-Caricetum colchicae (Simon 1960) Krausch, 1965, subass. ephedretosum Sanda et al., 1999; 1. Dune Omer/Letea 5.06.2003; 2-14 Dune Omer and proximity 08.09.2012.

\begin{tabular}{|c|c|c|c|c|c|c|c|c|c|c|c|c|c|c|c|}
\hline $\mathrm{P}$ & $\begin{array}{l}\text { Dianthus } \\
\text { bessarabicus }\end{array}$ & . & . & . & + & + & . & . & . & . & . & . & . & . & . \\
\hline & $\begin{array}{l}\text { Elymion } \\
\text { gigantei }\end{array}$ & . & . & . & . & . & . & . & . & . & . & . & . & . & . \\
\hline $\mathrm{P}$ & $\begin{array}{l}\text { Leymus } \\
\text { sabulosus }\end{array}$ & . & . & . & + & . & + & + & . & . & . & + & . & + & 1 \\
\hline . & $\begin{array}{l}\text { Festucion, } \\
\text { Festucetalia }\end{array}$ & & & & & & & & & & & & & & \\
\hline Eua & $\begin{array}{l}\text { Linum } \\
\text { austriacum }\end{array}$ & . & + & + & . & . & . & . & . & . & . & . & . & . & . \\
\hline Ct-Eua & $\begin{array}{l}\text { Linaria } \\
\text { genistifolia }\end{array}$ & + & . & . & . & . & . & . & . & . & . & . & . & + & . \\
\hline Ct-Eua & $\begin{array}{l}\text { Euphorbia } \\
\text { seguieriana }\end{array}$ & . & + & + & + & + & + & + & . & . & + & . & + & + & . \\
\hline Ct-Eua & $\begin{array}{l}\text { Silene } \\
\text { otites }\end{array}$ & + & . & . & + & . & . & . & . & . & . & . & . & . & . \\
\hline Eua-Ct & $\begin{array}{l}\text { Alyssum } \\
\text { desertorum }\end{array}$ & + & . & . & . & . & . & . & . & . & . & . & . & . & . \\
\hline & $\begin{array}{l}\text { Acompainying } \\
\text { species }\end{array}$ & & & & & & & & & & & & & & \\
\hline $\begin{array}{l}\text { Eua- } \\
\text { smed }\end{array}$ & $\begin{array}{l}\text { Scirpoides } \\
\text { holoschoenus }\end{array}$ & . & + & + & . & . & + & + & . & . & + & . & + & . & . \\
\hline Eua-Ct & $\begin{array}{l}\text { Erysimum } \\
\text { cuspidatum }\end{array}$ & . & + & + & . & + & + & + & + & . & . & + & . & . & + \\
\hline Ct-Eua & $\begin{array}{l}\text { Artemisia } \\
\text { santonicum }\end{array}$ & . & . & + & 2 & + & + & 1 & . & + & + & . & . & . & . \\
\hline Ct-Eua & $\begin{array}{l}\text { Kochia } \\
\text { prostrata }\end{array}$ & . & + & . & . & . & . & . & . & + & . & . & + & . & + \\
\hline Eur & $\begin{array}{l}\text { Berberis } \\
\text { vulgaris }\end{array}$ & . & . & . & • & . & . & . & . & + & . & . & . & . & . \\
\hline \multirow[t]{2}{*}{ Euras } & $\begin{array}{l}\text { Salix } \\
\text { rosmarinifolia }\end{array}$ & . & . & - & · & . & . & - & . & - & · & . & 1 & . & . \\
\hline & $\begin{array}{l}\text { Cladonia } \\
\text { furcata }\end{array}$ & 1 & . & . & . & . & . & 1 & 1 & . & . & 2 & . & + & . \\
\hline
\end{tabular}

Near Ephedra distachya and Carex colchica, Polygonum arenarium with high constancy and Euphorbia seguieriana have to be mentioned accompanied by other xerothermophilous species of Festuco-Brometea (Tab. 1).

The Sea grape (Ephedra distachya) is mentioned as edifying species in phytocoenoses of the association Koelerio glaucae-Stipetum borysthenicae (Popescu and Sanda, 1987) with species of the alliance Festucion vaginatae such are Euphorbia seguieriana (transgressive species of the Festuco-Brometea), Helichrysum arenarium, Dianthus bessarabicus and others. 
As the abundance-dominance and the frequency of Sea grape (Ephedra distachya) are in some area relatively high and with a clear ecological differentiation, vis-à-vis - the typical association of Scabioso argenteae-Caricetum colchicae - it is also justified to consider the subassociation ephedretosum as it is given by Sanda et al., 2008, again as an independent association Ephedro-Caricetum colchicae (Prodan 1939 n.n. Morariu, 1959) Sanda and Popescu, 1973. This opinion is documented also by Doniţă et al. (2005) for the habitat type R1603 including communities of Sea grape of the Ephedro-Caricetum colchicae.

Due to changes of the Danube hydrological regime and the dropping down of the groundwater table in the dune area Letea (Cioacă et al., 2005), the xerophilous steppe species increased and became dominant lately. This observation fits together with the observation of continuous expansion of the species mentioned by Sanda et al. (2008). According to field observation, a strong interlocking exists between the phytocoenoses of the different phytocoenological units, thanks to the micromosaic of the dunes morphological structure.

The above presented association Scabioso argenteae-Caricetum colchicae (Simon 1960; Krausch 1965), subass. ephedretosum Sanda et al., 1999 takes part of an entire vegetation complex, colonising the dune area and forming the characteristic habitat type 2130* fixed coastal dunes with herbaceous vegetation (grey dunes), subtype 16.22 B Pontic fixed dunes - fixed dunes of the coasts of the Black Sea. But the site conditions of the dunes are various in dependence of localisation on the slope (foot of the slope or upper part and top of the dunes), the inclination and exposition, making it difficult to include all the different phytocoenoses in the broad considered habitat type of grey dunes. In this context, it can be stated that the habitat with Sea grape (Ephedra distachya) is very good contoured and can be considered together with the structure of its schrubs as an independent habitat type.

Phytocoenoses with Ephedra distachya as characteristic and edifying species are described also from grey dunes in the North-Eastern part of Greece as association Ephedra distachya-Silene subconica Oberd. 1952 (Oberdorfer, 1952; Horvat et al., 1974). The phytcoenoses of this association are characterized besides Ephedra distachya and Silene subconica through the species Silene dichotoma, Centaurea cuneifolia, Fumana procumbens, Verbascum pinnatifidum, Jasione heldreichii, Corynephorus articulatus and Phleum arenarium. The composition of this association - including many Eurasian continental species - indicates the relation with the arid steppe area north of the Black Sea and the semi-desert of Asia (Horvat et al., 1974). Both associations, Ephedra distachya-Silene subconica of NorthEastern Greece and Scabioso argenteae-Caricetum colchicae subass. ephedretosum of the Danube Delta, are strongly related; their species of continental, Pontic and Mediterranean origin and their habitat structure being near one to the other.

The grey dune habitats of North-Eastern Greece can be considered as a connector between Pontic associations and their habitats with those lying more in the Southern and Western Grey dunes of the Mediterranean Sea which are included in the habitat type 2220 Dunes with Euphorbia terracina (EUR28, 2013). These are characterized as coastal dune grassland communities among others like Euphorbia terracina, Silene nicaeensis, Ephedra distachya and Silene subconica. In each case, the grey dunes of the Black Sea coast - as a part of the Pontic bioregion - cannot be further included as a subtype of the habitat type 2130 in the Habitat category of Sea dunes of the Atlantic, North Sea and Baltic coasts as it is given in the Interpretation Manual of European Union Habitats (EUR28, 2013). It had to be included either in the category of Sea dunes of the Mediterranean coasts, as there are strong relations between the Dunes of the Mediterranean and the Black Sea coasts, or in an independent category of Sea dunes of the Black Sea/Pontic bioregion. This is justified by the transition character between the Mediterranean dunes and those of the Pontic and continental area. The 
Black Sea particularity i.e. Pontic region is underlined as well by the Palaearctic classification, under the habitat number 1622B121, including North-Western Pontic Ephedra-Carex fixed dune and the EUNIS classification under B1.4B1 Western Pontic fixed dunes (Doniţă et al., 2005; Hanganu et al., 2015). The vegetation is a more or less open cover of Ephedra distachya and herbacous plants, as well in some places by lichens Cladonia ssp. The Western-Pontic character of the habitat is recognised also by Doniţă et al. (2005), where is mentioned as "Western Pontic communities with Carex colchica and Ephedra distachya".

The communities of Ephedra distachya on sandy dunes with their small scrubs constitutes a habitat with a particular structure, given by the ramified branches. This is favourable for the rare Steppic Lizard (Eremias arguta deserti), a Pontic-Caspian species (Oţel, 2000) living on the dry dunes, which offer them a favourable habitat with appropriate hiding and nutrition places.

The Sea grape (Ephedra distachya) occurs also in another habitat existing on the Romanian coast i.e. the rocky slopes of the Razim Lake, a former lagoon of the Black Sea, where it occurs together with Limonium species, constituting a habitat near those mentioned from the coast of the Mediterranean Sea under the habitat number 1240 Vegetated sea cliffs of the Mediterranean coasts with endemic Limonium ssp. (EUR28, 2013) (Fig. 5). This is also a habitat type which is rare on the Black Sea coast and needs comparative studies with similar habitats of the Mediterranean region for the clarification of its distribution area and position in the system of habitats of the European Union.

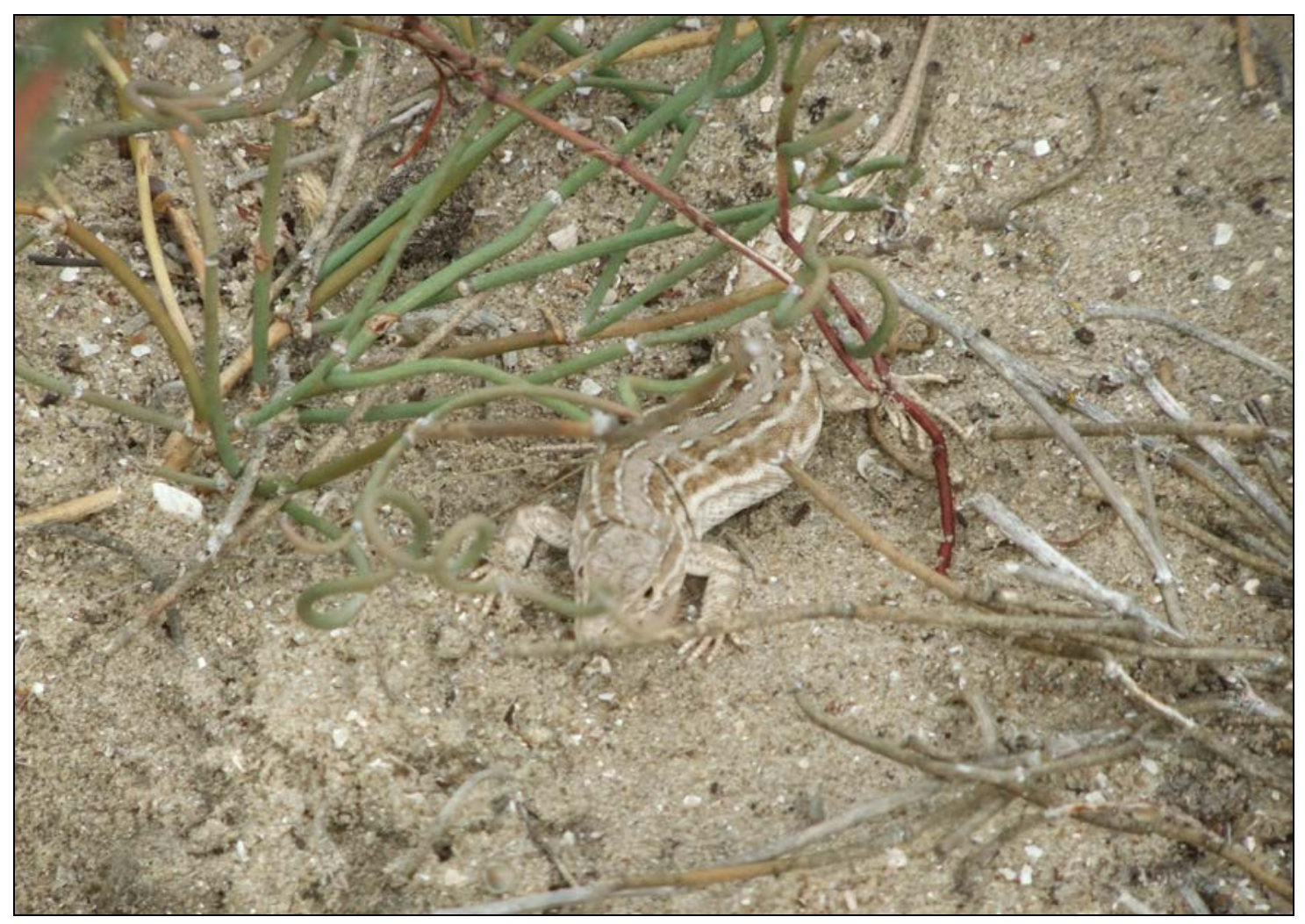

Figure 5: Dune with Sea grape (Ephedra distachya) a characteristic habitat for the Steppe Lizard (Eremias arguta) (photo Schneider E., 2011). 


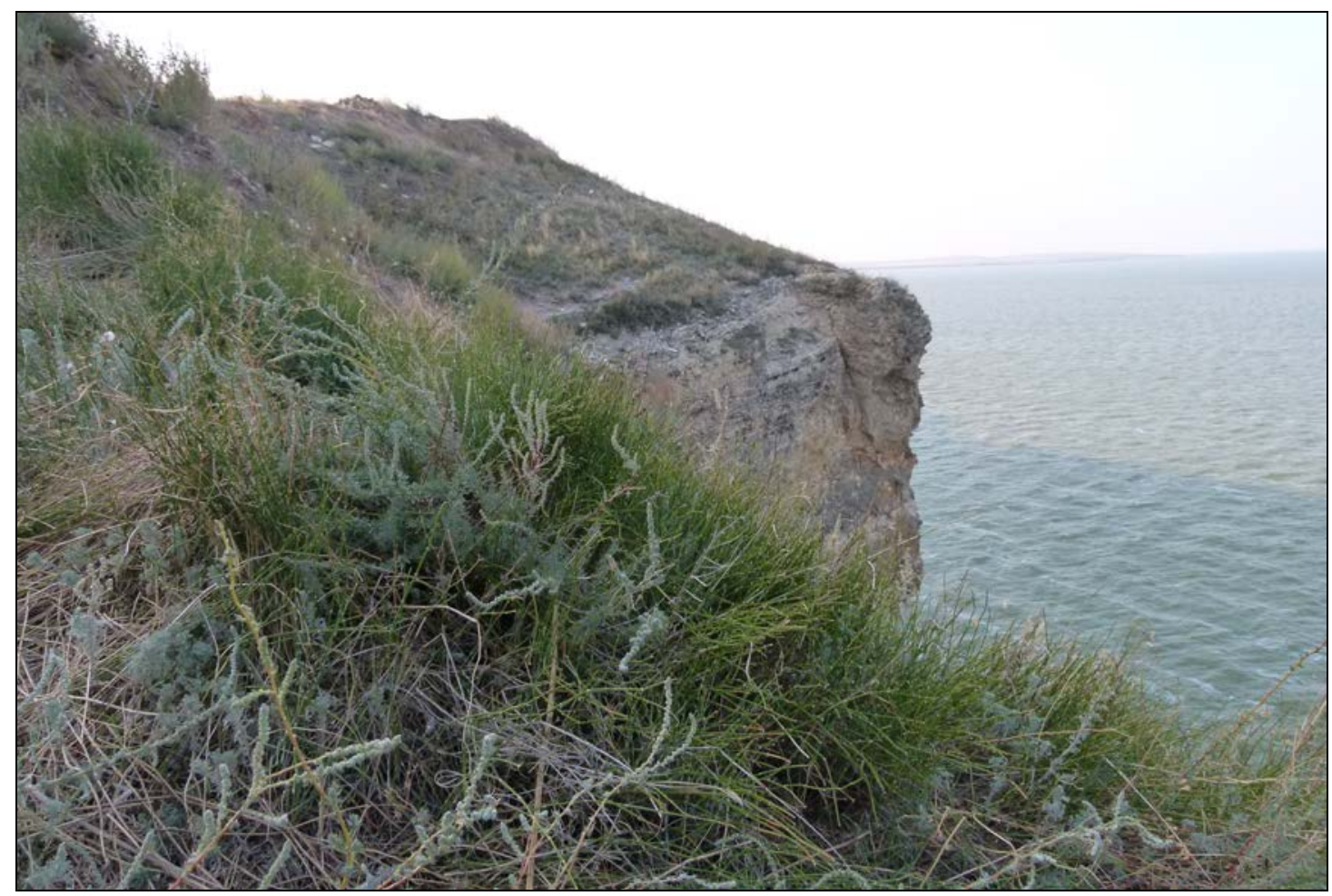

Figure 6: Rocky slopes on the Razim Lake (Danube Delta Biosphere Reserve) with Ephedra distachya, Kochia prostrata and Limonium meyeri (photo Kuhlke F., 2011).

\section{CONCLUSIONS}

Considering the species composition of the habitat type with many species with Pontic, Pontic-Mediterranean and Eurasian-Continental distribution, it can be stated that the dune habitat with Sea grape (Ephedra distachya) is characteristic for the Pontic and Mediterranean bioregion. This is why the inclusion of such a habitat subtype in the habitat type category of "Sea dunes of the Atlantic, North Sea and Baltic coasts" is not appropriate and has to be changed.

The proposal is to include it in the category of Mediterranean dune habitats and to generalise this as a habitat type category under the name of "Sea dunes of the Mediterranean and the Black Sea coast", or to introduce in the Interpretation Manual a new, additional category of habitat types characteristic for the Pontic bioregion under the name "Sea dunes of the Pontic - Black Sea bioregion". This proposal is justified as in the Palaearctic classification of habitats is mentioned the habitat 16.22B 121 North-Western Pontic Ephedra-Carex fixed dunes and in the EUNIS classification the habitat B 1 4B1 Western Pontic fixed dunes.

In the frame of habitats of grey dunes, the Sea grape (Ephedra distachya) communities are different in their structure compared to the small schrub constituting a more independent habitat type in comparison with other components i.e. microhabitats included in the large habitat type of grey dunes. 


\section{REFERENCES}

1. Antipa G., 1911 - Das Überschwemmungsgebiet der unteren Donau, Anuarul Institutului Geologic al României, IV, 11, 224-496, XXIII Anexes of profiles, other graphics and maps, Bucureşti. (in German)

2. Borza A., 1931 - Die Exkursionsroute durch die Dobrogea und das Donaudelta, Guide de la sixième excursion phytogéographique internationale, Roumanie, 130-144. (in German)

3. Borza A. and Boşcaiu N., 1965 - Introducere în studiul covorului vegetal, Edit. Academiei Republicii Socialiste România, Bucureşti, 341. (in Romanian)

4. Braun-Blanquet J., 1964 - Pflanzensoziologie, Auflage, Wien, 3, 865. (in German)

5. Cioacă E., Dimache D. and Schneider-Binder E., 2005 - Hydrological regime within the Danube Delta Biosphere Reserve - Letea forest ecosystem case study, Scientific Annals of the Danube Delta Institute, Edit. Tehnică Tulcea, 11, 142-151.

6. Ciocârlan V., 1994 - Flora Deltei Dunării, Cormophyta, Edit. Ceres, Bucureşti, 115. (in Romanian)

7. Ciocârlan V., 2009 - Flora ilustrată a României, Pteridophyta et Spermatophyta, Edit. Ceres, 1141. (in Romanian)

8. Doniţă N., Popescu A., Paucă-Comănescu M., Mihăilescu S. and Biriş I. A., 2005 - Habitatele din România, Edit. Tehnică Silvică, Bucureşti, 496. (in Romanian)

9. EUR28, 2013 - Interpretation Manual of the European Union habitats, European Commission DG Environment, 144.

10. Făgăraş M., 2002 - Contribuţii la cunoaşterea ecologică a florei şi vegetaţiei de la litoralul românesc al Mării Negre, Teză de doctorat, Universitatea Ovidius, Constanţa. (in Romanian)

11. Gafta D. and Mountford O. (eds), 2008 - Manual de interpretare a habitatelor Natura 2000 din România, Risoprint, Cluj-Napoca, 101. (in Romanian)

12. Gâştescu P. and Ştiucă R., 2008 - Delta Dunării. Rezervaţie a Biosferei, Edit. CD Press, Bucureşti, 400. (in Romanian)

13. Grinţescu G., 1952 - Familia Ephedraceae Rchb, in Flora Republicii Popularea Române, I, 182-188, Edit. Academiei Republicii Populare Române, Traian Săvulescu, Bucureşti. (in Romanian)

14. Hanganu J., Doroftei M., Sârbu I. and Ştefan N., 2015 - Distribution of the vegetation within the Danube Delta, Part I, Physical Landscape, 1, 3-38, in Iordachi C. and van Assche K. (eds): The bio-politics of the Danube Delta, Lexington Books Lanham Boulder, New York, London, 452.

15. Horvat I., Glavac V. and Ellenberg H., 1974 - Vegetation Südosteuropas, Vegetation of SouthEastern Europe, VEB Gustav Fischer Verlag Jena, 768. (in German)

16. Krausch H. D., 1965 - Vegetationskundliche Beobachtungen im Donaudelta, Limnologica, (Berlin), 3, 3, 271-373. (in German)

17. Oberdorfer E., 1952 - Beitrag zur Kenntnis der nordägäischen Küstenvegetation, Vegetatio, 3, 29-349. (in German)

18. Oberdorfer E., 2001 - Pflanzensoziologische Exkursionsflora für Deutschland und angrenzende Gebiete, Auflage, Verlag Eugen Ulmer Stuttgart, 8, 1051. (in German)

19. Oprea A., 2005 - Lista critică a plantelor vasculare din România, Edit. Universităţii “Alexandru Ioan Cuza”, Iaşi, 668. (in Romanian)

20. Oţel V. (ed.), 2000 - The red list of plant and animal species from the Danube Delta Biosphere Reserve Romania, Fundaţia Aves, 132, 48 figures and map.

21. Popescu A. and Sanda V., 1987 - Structura vegetaţiei din clasa Festucetea vaginatae Soo 1968 de pe teritoriul României, Culegere de Studii şi Articole de Biologie, Universitatea “Alexandru Ioan Cuza”, Iaşi, 3, 225-235. (in Romanian)

22. Sanda V., Öllerer K. and Burescu P., 2008 - Fitocenozele din România, Sintaxonomie, structura, dinamica şi evoluţie, Ars Docendi, Universitatea din Bucureşti, 570. (in Romanian) 
23. Sanda V. and Popescu A., 1973 - Cercetări privind flora şi vegetaţia din Delta Dunării, Studii şi Cercetări de Biologie, Seria Botanică, Bucureşti, 25, 5, 399-424. (in Romanian)

24. Sârbu I., Ştefan N., Hanganu J., Gridin M. and Coroi M., 1995 - Vegetaţia de pe Grindul Chituc în corelaţie cu tipul de substrat, Analele Ştiinţifice ale Institutului Delta Dunării ICPDD, Tulcea, 4, 1, 201-203. (in Romanian)

25. Sârbu I., Ştefan N. and Oprea A., 2013 - Plante vasculare din România, Determinator ilustrat de teren, Edit. Victor B. Victor, Bucureşti, 123, 1. (in Romanian)

26. Schneider E., 2015 - The Impact of the Hydrological Regime on the Diversity of Natural Habitats in the Danube Delta. Part I Physical Landscape, Chapter 2, 39-66, in Iordachi C. and van Assche K. (eds), The bio-politics of the Danube Delta: Lexington Books Lanham, Boulder, New York, London, 452.

27. Schneider E., Dister E. and Döpke M., 2009 - The Lower Danube Green Corridor Atlas, 27 and 15 maps, Publication of WWF-Germany.

28. Simon T., 1960 - Contributions à la conaissance de la végétation du delta du Danube, Annales Universitatis Scientiarum Budapestinensis de Rolando Eötvös, Sectio Biologica, 3, 307-333. (in French) 